\title{
Marcin Laberschek
}

\section{IDENTYFIKACJA PÓL WARTOŚCI PRODUKTU KULTURY}

\section{Abstract \\ IDENTIFICATION OF CULTURE PRODUCT VALUE FIELDS}

When we analyse some products, we could take into consideration not only their physical side. What is more, we could reach their incorporeal level, in other words the subjective value that is born in the consciousness and unconsciousness of customers. In this article, we take into account the cultural products and indicate what symbolic values are responsible for the fact that these products are appreciated by customers. To do this, we create and use an analytical tool: fields of the product value. Moreover, the tool could be also useful when it comes to conducting marketing research, both by researchers and manufacturers, who are trying to understand hidden mechanisms, which are responsible for choices not only of cultural market participants, but also other markets.

SŁOWA KLUCZE: produkt kultury, zarządzanie produktem kultury, pola wartości produktu, wyobraźnia w zarządzaniu, wyobrażenie produktu, symboliczne znaczenie produktu, konsument produktu kultury, jakościowe badania marketingowe

KEY WORDS: cultural product, management of cultural product, fields of the product value imagination in management, product imaginery, symbolic product meaning, cultural product consumer, qualitative marketing research

\section{Ujęcie estetyczne w naukach o zarządzaniu}

Tematyka artykułu wpisuje się w obszar zarządzania marketingowego, a konkretnie metodologii badań marketingowych i zarządzania produktem. Tłem epistemologicznym nie jest jednak obiektywizująca perspektywa modernistyczna, lecz ujęcie humanistyczne. Wiąże się ono nierozerwalnie z eksploracją przejawów kultury w społecznych procesach zarządzania. Początek zainteresowania kulturą w naukach 
o organizacji i zarządzaniu przypada na lata osiemdziesiąte XX wieku ${ }^{1}$ i zyskuje coraz większe uznanie w aktualnych dyskusjach akademickich.

Dla humanistycznej perspektywy w naukach o zarządzaniu charakterystyczne jest ujęcie antropocentryczne, gdzie ,człowiek stanowi punkt wyjścia i punkt odniesienia wszystkich działań ludzkich"2. Bynajmniej nie kierujemy się tutaj w stronę pokładów ludzkiego egoizmu i megalomanii (to paradygmat funkcjonalistyczny, w przeciwieństwie do humanistycznego, może zakładać taką optykę, np. idea menedżeryzmu). Chodzi natomiast o antropocentryzm, gdy o materii relacji społecznych nie możemy nic powiedzieć bez obecności człowieka, który jej doświadcza i ją poznaje. To człowiek jest interpretatorem świata, więc tylko taki jego obraz jest nam dostępny. Wszystkie zachowania społeczne pojmuje się więc subiektywnie i odczytuje symbolicznie, traktując jako przejawy kultury. W szerokim ujęciu humanistycznym kultura jest więc obrazem wszystkich aspektów życia społecznego.

Inną orientację w zarządzaniu humanistycznym nazwiemy ujęciem estetycznym. Jest ono umocowane i wywodzi się ze wspomnianego szerszego nurtu antropocentrycznego - również tutaj interesują nas społeczne zjawiska organizacyjne postrzegane przez subiektywny pryzmat. Dotykamy jednak sfery, która jest traktowana peryferyjnie w szerszym ujęciu. Chodzi mianowicie o ludzką wrażliwość i jej znaczenie w społecznych procesach zarządzania. Wrażliwość może odnosić się do ludzkiej moralności, w której „,nadanie cech troski o człowieka każdemu wymiarowi zarządzania"3 oraz odnajdywanie i zachowanie godności, istotę której w Liście o humanizmie podkreślał Martin Heidegger ${ }^{4}$, to fundamentalne założenia. Wrażliwość może się także wyrażać w ludzkich przeżyciach duchowych, religijnych i emocjonalnych. Może się też ujawniać w twórczości artystycznej i szeroko rozumianej kreatywności człowieka. Te wszystkie elementy będą zatem stanowiły o jego potencjale estetycznym. Poszukiwania przejawów kultury wobec tego nie będą koncentrowały się na doświadczaniu oraz interpretacji interakcji społecznych, ale na eksploracji i analizie „sfery wyobraźni”, jak sygnalizuje Monika Kostera ${ }^{5}$. Kulturą w tym wypadku będzie więc estetyczny potencjał człowieka (moralny, duchowy, artystyczny czy kreatywny). Można stwierdzić, że badacz, który preferuje estetyczne ujęcie badawcze w naukach o zarządzaniu, koncentruje się na kulturowych atrybutach jednostki, traktując je jako punkt odniesienia do zrozumienia relacji społecznych w oragnizacji lub jej otoczeniu.

${ }^{1}$ M. Kostera, Antropologia organizacji. Metodologia badań terenowych, Warszawa 2003, s. 40; P. Krzyworzeka, Kultura i organizacje. Perspektywa antropologiczna [w:] B. Glinka, M. Kostera (red.), Nowe kierunki w organizacji i zarzadzaniu. Organizacje, konteksty, procesy zarzadzania, Warszawa 2012, s. 62-78.

2 B. Czarniawska, Zarzadzanie humanistyczne czy zarządzanie ludzkie? [w:] B. Nierenberg, R. Batko, Ł. Sułkowski (red.), Zarządzanie humanistyczne, Kraków 2015, s. 15-22.

${ }^{3}$ E. Orzechowski, Arte et ratione [w:] B. Nierenberg, R. Batko, Ł. Sułkowski (red.), Zarzqdzanie humanistyczne, Kraków 2015, s. 63-74.

${ }^{4}$ M. Heidegger, Budować, mieszkać, myśleć. Eseje wybrane, Warszawa 1977, s. 84.

${ }_{5}^{5}$ M. Kostera, Collage narracyjny [w:] M. Kostera (red.), Metody badawcze w zarzadzaniu humanistycznym, Warszawa 2015, s. 81-91. 
Ujęcie estetyczne należy traktować odrębnie, gdyż znalazło ono szczególne miejsce nie tylko $\mathrm{w}$ interesującej nas dyscyplinie. W ostatnich latach powstaje wiele prac naukowych opartych na tej koncepcji, zarówno w obszarze zarządzania i teorii organizacji ${ }^{6}$, jak i związanych z nimi dziedzinach ekonomii ${ }^{7}$ i marketingu ${ }^{8}$. W monografiach tych podjęto próbę wytłumaczenia zjawisk społecznych z punktu widzenia kultury i różnych jej aspektów, w tym: etyki, emocji, twórczości czy duchowości, zachowując stosowny dystans do miar ilościowych. Takie stanowisko wobec problematyki zarządzania produktem przyjęte jest $\mathrm{w}$ także niniejszym artykule.

\section{Przybliżenie tematyki i celu pracy}

W ramach opracowania przyjrzymy się produktom kultury, by sprawdzić, jakie immanentne i niematerialne ich elementy świadczą o tym, że produkt znajduje uznanie wśród potencjalnych nabywców. Wskażemy, że elementy te skupiają się wokół trzech pól wartości: użyteczności, spekulacji i estetyki, które wspólnie tworzą ,ukrytą" symboliczną tkankę produktu kultury. Dokonamy pogłębionej analizy każdego z tych pól, przyjrzymy się też ich wzajemnym relacjom.

Idea pól wartości może być istotna $\mathrm{z}$ dwóch punktów widzenia. Po pierwsze, z punktu widzenia producentów działających na rynku kultury. Wiedza o tym, co powinien zawierać wytwór artystyczny, by w świadomości określonej grupy odbiorców go odbiorców jawił się jako wartościowy, a także o tym, na które spośród tych elementów kładzie akcent konkurencja, ma bowiem dla producentów zasadnicze znaczenie. Po drugie, koncepcję tę samą w sobie można wykorzystać jako jakościowe narzędzie, pomocne w prowadzeniu badań marketingowych. Dzięki niemu badacze rynku kultury (choć nie tylko kultury) będą mogli zidentyfikować i zinterpretować „ukryte” symboliczne warstwy produktu kultury, które stanowią o jego wartości dla odbiorcy. Przez zgłębienie tego, co „ukryte” w produkcie, uzyskać można wewnętrzny portret nabywcy; utworzyć nie tyle personę, ile profil jej uświadomionych i nieuświadomionych potrzeb, pragnień, wartości etc. Można także zrozumieć, jakie symboliczne strategie kierowały twórcą produktu przy jego tworzeniu. Ujęcie to nawiązuje do koncepcji „dzieła otwartego” Umberta Eco, dzięki której, przeprowadzając analizę semiotyczną tekstu literackiego, możemy odkryć zarówno modelowego autora, jak i czytelnika dzieła, których wizerunek jest zawarty w samej ,intencji tekstu"9. Oczywiście, analizę semiotyczną można wykorzystać nie tylko do

${ }^{6}$ Choćby: M.J. Hatch, M. Kostera, A. Koźmiński, Trzy oblicza przywództwa. Menedżer, artysta, kaptan, Warszawa 2010; A. Strati, Organization and Aesthetics, London 1999.

7 Np.: B.J. Pine, J.H. Gilmore, The Experience Economy: Work is the Theater and Every Business a Stage, Boston 1999; T. Sedlaček, Ekonomia dobra i zła, Warszawa 2012.

8 Jak: B. Schmitt, A. Simonson, Estetyka w marketingu, Kraków 1999; G. Zaltman, L. Zaltman, Metafora w marketingu, Poznań 2010.

${ }^{9}$ U. Eco, Dzieło otwarte: forma i nieokreśloność w poetykach współczesnych, Warszawa 1973, s. $63-64$. 
interpretacji tekstów literackich, ale też w celu zgłębienia istoty wszelkich innych kreatywnych wytworów człowieka. Różnicę stanowi jednak fakt, że w „intencji produktu kultury” może być „schowane” coś więcej niż to, co przedsięwziął jego twórca.

\section{Między produktem a produktem kultury}

W naukach o zarządzaniu termin „,produkt” najczęściej pojawia się w opracowaniach marketingowych. By właściwie podejść do tematu, w pierwszej kolejności odwołajmy się do ujęcia klasycznego. Philip Kotler definiuje produkt jako: „wszystko, co może zostać zaoferowane na rynku w celu zaspokojenia jakiejś potrzeby" ${ }^{10}$. Zauważmy, że badacz stwierdził, iż produkt tylko „może” być wprowadzony na rynek, natomiast nie wspomniał o konieczności zaistnienia takiego aktu. Produktem jest więc „coś”, co tylko może, ale nie musi być przedmiotem wymiany rynkowej. W takim razie to nie aspekt rynkowy decyduje o tym, czy „coś” jest produktem, czy też nim nie jest. Powinniśmy zadać zatem pytanie: co stanowi istotę produktu, czym jest to „coś”? Kotler podaje kilka przykładów produktów: „dobra fizyczne, usługi, przeżycia, wydarzenia, osoby, miejsca, organizacje, informacje oraz idee"11. Poszukajmy zatem wspólnego pozarynkowego mianownika dla tych produktów. Odpada aspekt materialny produktu (gdyż mamy takie produkty, jak wydarzenia czy idee). Tylko niektóre z nich mają pochodzenie naturalne (jak choćby: miejsca przyrodnicze czy niektóre dobra fizyczne, np. surowce naturalne) i tylko część produktów może być precyzyjnie określona w sensie fizycznym (np. dobra fizyczne, osoby, miejsca). Jednakże każdy produkt ma swoją niematerialną, „ukrytą”, czyli symboliczną warstwę. Dotyczy to zarówno „nowoczesnych” produktów z rynku doznańn ${ }^{12}$, które - odpowiednio zaprojektowane - w szczególny sposób oddziałują na odczucia klientów, ale też - chociaż w zasadniczo mniejszym stopniu - dóbr codziennego użytku. Dla przykładu, człowiek nie postrzega przecież cukru jako „usypiska maleńkich kryształków", ale przychodzą mu na myśl różnego rodzaju konotacje - pozytywne, np.: przyjemność, słodycz, ciasto, lub negatywne, np. otyłość, cukrzyca. Do warstwy symbolicznej mogą się także odwoływać opakowanie cukru oraz elementy mające uwarunkowanie społeczno-rynkowe, takie jak marka czy cena. W niniejszym opracowaniu koncentrować się będziemy na symbolicznej warstwie produktów i postrzegać je tak, jak produkty ludzkiej wyobraźni.

W artykule zajmiemy się specyficznym rodzajem produktów, a mianowicie produktami kultury. Są to wszelkie materialne i niematerialne wytwory, u podstaw których tkwi artystyczny, kreatywny i duchowy potencjał człowieka. Mogą to być:

${ }_{10}$ P. Kotler, Marketing, Poznań 2005, s. 409.

11 Tamże.

12 Zob.: B.J. Pine, J.H. Gilmore, The Experience Economy: Work is the Theater and Every Business a Stage, Boston 1999; M. Kostera, Zarzadzanie na rynku doznań [w:] B. Glinka, M. Kostera (red.), Nowe kierunki w organizacji i zarzadzaniu. Organizacje, konteksty, procesy zarzadzania, Warszawa 2012, s. 361-375. 
utwory muzyczne, rzeźby, książki, czasopisma, programy telewizyjne czy też wydarzenia artystyczne jako całość (np. festiwale muzyczne, konkursy literackie). Przykładów produktów kultury jest bardzo wiele, a ich lista jest otwarta i ustawicznie się powiększa. Oprócz bowiem tradycyjnie pojmowanych kategorii artystycznych coraz częściej dołączają nowe, które związane są z twórczością wykorzystującą możliwości, jakie stwarzają nowe technologie. Do produktów kultury coraz częściej zalicza się także wytwory kreatywne z kręgu mody, dizajnu, architektury czy też reklamy. W oryginalny sposób do tego tematu podszedł David Throsby, który w formie koncentrycznych kręgów zaprezentował zjawisko poszerzania się obszaru, w ramach którego skupia się różnego rodzaju działalność kulturalna ${ }^{13}$.

Warto zwrócić uwagę, że stawianie w jednym szeregu produktów kultury różnego „formatu” wzbudzało i wzbudza wiele kontrowersji zarówno w środowiskach artystów, jak i naukowych. Theodor Adorno, przedstawiciel szkoły frankfurckiej, zajął w tej sprawie kategoryczne stanowisko. Stanowczo podkreślił, iż w modernistycznej rzeczywistości naturalny podział na sztukę wysoką i niską jest sztucznie zacierany przez kapitalistyczny przemysł kulturalny. Jest on jest nakierowany na osiąganie zysku, masowo wytwarza więc sztukę niskiej jakości i standardową. Odbiorca, który nie jest podmiotem, a przedmiotem rynkowym zostaje zmanipulowany: nie ma świadomości standaryzacji produktu, posiada natomiast złudne przeświadczenie doświadczenia czegoś wyjątkowego, indywidualnego. Jest biernym „obiektem spekulacji” producentów towarów kultury ${ }^{14}$. Postmarksistowskie określenie „towar” odnoszące się do produktu kultury masowej ma szczególny, negatywny wydźwięk. Adorno podkreśla bowiem, że w społeczeństwie kapitalistycznym cena towaru kultury ma większe znaczenie niż jego treść. Wartość wymienna towaru bierze górę nad użytkową ${ }^{15}$. Tymczasem współcześni przedstawiciele nurtu krytycznego, nawiązujący do koncepcji Adorna, nie są już tak radykalni. Co prawda oddzielają kulturę elitarną od popularnej, nie podkreślają natomiast dominującej pozycji producentów wobec biernych odbiorców kultury. Podkreślają jednocześnie, że kierunek oddziaływania może być odwrotny - spontaniczny, kiedy to odbiorcy mogą kształtować trendy ryn$k_{\text {kowe }}{ }^{16}$. Narracja niniejszego opracowania wpisuje się jednakże w kontekst odrębnego dyskursu - postmodernistycznego, w którym akcentuje się to, iż próby postawienia wyraźnej granicy pomiędzy kulturą masową a elitarną z góry skazane są na porażkę: „Nie ma już żadnych ustalonych i niepodważalnych kryteriów służących ich odróżnianiu” ${ }^{17}$. A skoro nie ma „gorszych” i „lepszych” produktów kultury, wszystkie potraktujmy łącznie i dokonajmy eksploracji ich wspólnej „ukrytej” warstwy.

\footnotetext{
13 D. Throsby, Ekonomia i kultura, Warszawa 2010, s. 104.

14 T. Adorno, The Culture Industry, London 1991, s. 85-87.

15 Tamże, s. 34.

16 J. Fiske, Zrozumieć kulturę popularna, Kraków 2010, s. 23.

17 D. Strinati, Wprowadzenie do kultury popularnej, Poznań 1998, s. 180.
} 
W Kapitale Karol Marks twierdził, że każdy towar składa się z dwóch immanentnych płaszczyzn: z wartości użytkowej i wymiennej ${ }^{18}$. Ta pierwsza odwołuje się do materialnej strony dobra i oznacza „ciało towaru”. Ciałem jest to, co stanowi fizykalną, mierzalną istotę towaru (np. materiał, z którego go wytworzono). Marks zauważa, że ciało towaru nie istnieje poza nim samym - ,nie wisi w powietrzu”. Tymczasem wskazuje również, że wartość użytkowa „urzeczywistnia się tylko przez użycie lub spożycie"19. Być może wartość ta nie jest więc przymiotem wyłącznie samego przedmiotu, ale także nieprzeliczalnym znaczeniem powstałym w świadomości człowieka za sprawą doświadczenia tego przedmiotu. Marks zauważa co prawda, że wartość użytkową towaru można określić społecznie - poprzez nakład pracy niezbędny do jego wytworzenia. Pomija jednak aspekt subiektywny, kiedy to wartość towaru ma wymiar indywidualny. Tę wątpliwość jeszcze wyjaśnimy, podnosząc temat użyteczności.

Drugi element towaru, nazwany wartością wymienną, odnosi się do ,formy społecznej" towaru. Społeczny aspekt tej wartości polega na tym, że jest ona wyrażona w rynkowej relacji (pozostaje w ,stosunku wymiennym”) z innymi towarami w ten sposób, iż dana ilość jakiegoś dobra odpowiada konkretnej ilości innego dobra ${ }^{20}$. Stosunek ten nie jest trwały, lecz konstruowany w relacjach społecznych.

Inspiracje dualnym podziałem towarów Marksa odnajdziemy w pracach wielu badaczy nurtu krytycznego, również tych, którzy zajmują się zagadnieniami kultury masowej i popularnej. John Fiske rozszerzył ideę Marksa i zastosował ją do analizy towarów z rynku popkultury. Uważa on, że towary popkulturowe (odnosi się to zresztą także do innych produktów konsumpcyjnych) są „,przynależne zarówno gospodarce finansowej, jak i kulturowej” ${ }^{21}$. Dlatego też „towary mają dwie funkcje do spełnienia: materialną i kulturową"22. Pierwsza funkcja, jak u Marksa, realizuje się za sprawą „cielesnych” elementów produktu, kulturowa natomiast „odpowiada za rozpowszechnianie znaczeń i dostarczanie przyjemności" ${ }^{23}$, dzięki którym nabywca konstruuje „własne ja, tożsamość społeczną oraz relacje społeczne”24. Wydaje się, że poprzez nadanie ,społecznej” warstwie produktu cech „kulturowych” Fiske zwiększył jej znaczenie w odniesieniu do wyszczególnionej przez Marksa „wartości wymiennej”. Tymczasem wartość warstwy „użytkowej” czy też „materialnej” została zmarginalizowana. W tym opracowaniu podkreślimy jednak znaczenie tej drugiej i obie będziemy traktować jako równie ważne; wykażemy, że wartości „użytkowe” wielu produktów kultury mogą mieć istotne znaczenie dla odbiorców. W tym celu

\footnotetext{
${ }_{18}$ K. Marks, Kapitat, Warszawa 2012.

19 Tamże.

20 Tamże.

${ }^{21}$ J. Fiske, Zrozumieć..., s. 27.

22 Tamże, s. 14.

23 Tamże, s. 26.

${ }^{24}$ Tamże, s. 14.
} 
przeprowadzimy debatę na temat tego, czym jest pole użyteczności i jak właściwie należy podejść do kwestii przydatności produktu kultury .

W tym miejscu jednak, podsumowując dotychczasową dyskusję, wyodrębnijmy pola wartości produktu kultury. Pierwsze nazwijmy, jak wspomnieliśmy powyżej, polem użyteczności, które nawiązuje do „użytkowej”, czy też „materialnej” płaszczyzny produktu, drugie, związane ze „społeczną” czy „kulturową” przestrzenią, określmy polem spekulacji. Jednakże produkty kultury posiadają też wyróżniające je trzecie pole.

Weźmy pod uwagę to, że w opinii wielu badaczy produkty kultury są specyficznym rodzajem wytworów, które różnią się od innych dóbr konsumpcyjnych ${ }^{25}$. David Throsby wyszczególnia charakterystyczny rodzaj wartości, który wyróżnia dobra kultury. Chodzi mianowicie o wartość kulturową ${ }^{26}$. Jak twierdzi autor, na wartość kulturową, właściwą każdemu produktowi kultury, składają się inne pomniejsze wartości: estetyczna, duchowa, społeczna, historyczna, symboliczna (transfer sensów), a także autentyczności ${ }^{27}$. W kontekście przeprowadzonych dociekań dokonajmy jednak stosownego ich uporządkowania. Jeśli do wartości estetycznej według Throsby'ego należą takie przymioty, jak na przykład piękno, harmonia czy forma ${ }^{28}$, to ten rodzaj wartości musi zawierać w sobie również wymiar duchowy. Nie można bowiem wyobrazić sobie twórczego piękna bez duchowego uniesienia artysty. Z kolei takie wartości, jak: historyczną, symboliczną i autentyczności, można z powodzeniem połączyć ze społeczną, jako że każda z nich realizuje się społecznie: historia jest wspólną opowieścią stworzoną w taki sam sposób, w jaki skonstruowana społecznie jest autentyczność oraz znaczenia symboliczne. Dzięki powyższemu uporządkowaniu utworzyliśmy dwie odrębne kategorie wartości: estetyczną i społeczną, które współtworzą wartość kulturową produktu kultury. Dokonajmy teraz kolejnej sensownej operacji. Przenieśmy wartość społeczną we właściwe miejsce, czyli tam, gdzie lokowali ją Marks i Fiske. To miejsce leżące obok pola użyteczności produktu, nazwane przez nas polem spekulacji. W ten oto sposób pozbawiliśmy stworzoną przez Throsby'ego wartość kulturową wymiaru społecznego i wyodrębniliśmy trzecie pole wartości produktu kultury, które nazwiemy polem estetyki ${ }^{29}$.

Podsumowując powyższe, zauważmy, że stworzyliśmy obraz produktu kultury złożony z trzech pól wartości: użyteczności, spekulacji i estetyki. Poglądowo przedstawia to il. 1. Na marginesie warto zaznaczyć, że choć pojęcie ,pola” może nasuwać skojarzenia z koncepcją Pierre'a Bourdieu, w naszym jednak wypadku związane jest ono z określonymi kategoriami symbolicznych korzyści w odniesieniu do produktu, a nie z ,przestrzenią społeczną”, rozumianą jako „pole walki” tworzących je ,,agensów” oraz ,pole sił”, które na nich oddziałują ${ }^{30}$.

${ }^{25}$ D. Throsby, Ekonomia..., s. 20; D. Ilczuk, Ekonomika kultury, Warszawa 2012, s. 30-31.

${ }^{26}$ D. Throsby, Ekonomia..., s. 37-41.

27 Tamże, s. 39-40.

28 Tamże, s. 39.

${ }^{29}$ Oczywiście, chodzi tu o „estetyczną” stronę produktu kultury, a nie o „estetyczne” ujęcie w naukach o zarządzaniu, drugie pojęcie jest bowiem kategorią epistemologiczną.

${ }^{30}$ P. Bourdieu, Rozum praktyczny. O teorii działania, Kraków 2009, s. 41. 


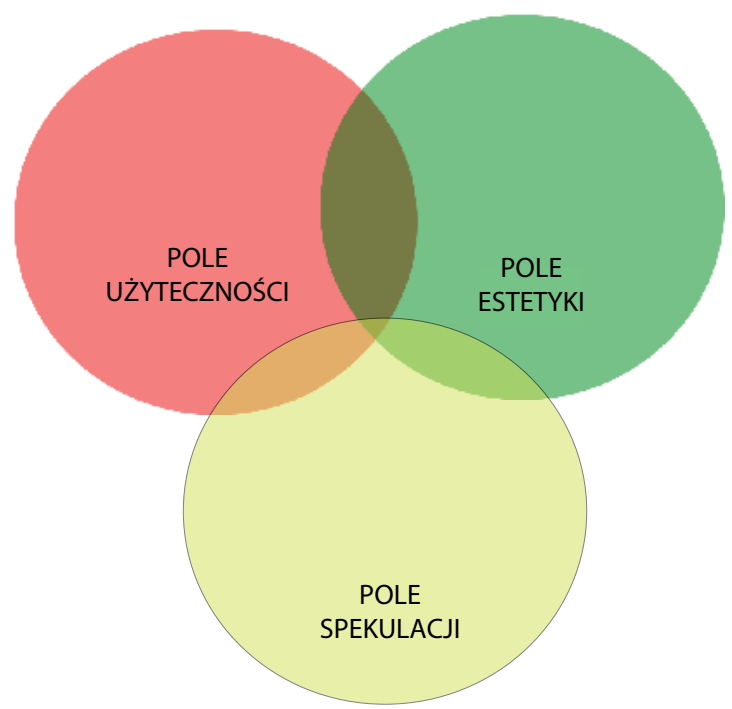

II. 1. Schemat koncepcji pól wartości produktu kultury

Źródło: opracowanie własne

Każde z wyodrębnionych przez nas trzech pól będziemy postrzegać niematerialnie. Pole użyteczności nie dotyka bowiem materialnych cech produktu, lecz symbolicznych jego znaczeń, które jawią się w świadomości konsumenta, a które wiążą się z jego osobistymi korzyściami, jakich dozna, gdy spożytkuje produkt. To tak, jakby konsument zadał sobie pytanie: „Dlaczego z mojego punktu widzenia produkt ten jest dla mnie wartościowy?”. Pole spekulacji również odnosi się do symbolicznych znaczeń ujawniających się w świadomości konsumenta, które wiążą się z jego osobistymi korzyściami, których jednak dozna w innej sytuacji: gdy stanie się użytkownikiem społecznej wartości produktu. W tej sytuacji pytanie zadane przez konsumenta może brzmieć: „Dlaczego ze społecznego punktu widzenia produkt ten jest dla mnie wartościowy?". Dwa powyższe pola wartości odnoszą się do świadomych obszarów jaźni człowieka, dlatego też nabywca może zupełnie świadomie określić to, dlaczego jeden produkt bardziej, a inny jest dla niego mniej wartościowy. Te dwa pola określają przestrzeń ,ja" człowieka, ale wskazują też to, że ,ja" ma dwoisty charakter. Zauważmy bowiem, że ,ja” kształtuje się zarówno w relacji do siebie - na linii ,ja-ja”, jak i w nawiązaniu do społeczeństwa - ,ja-oni”.

Tymczasem trzecie pole - estetyki, związane jest z nieświadomością człowieka. Mamy do czynienia niejako z intuicyjną osobliwością tego pola. W świadomości odbiorcy produktu kultury nie pojawiają się jego czytelne znaczenia. Nie potrafi on sprecyzować, dlaczego produkt jest dlań wartościowy, jakie przedstawia korzyści. Nieokreślone „coś” przyciąga jednak jego uwagę (albo przeciwnie, wzbudza niechęć). Na płaszczyźnie doświadczenia estetycznego odbiorca może jedynie stwierdzić: „Z pewnego powodu produkt ten jest dla mnie wartościowy”. Ten powód ma jednak wymiar wieloznaczny. Można go odczuć, ale nie sprecyzować. 
Podkreślmy w tym miejscu jedną sprawę. Otóż koncepcja pól wartości produktu łagodzi spór pomiędzy naukowcami krytykującymi wytwory kultury masowej i oddzielającymi je od kultury elitarnej a badaczami, którzy zwracają uwagę na to, że wszystkie produkty kultury mogą spełniać pozytywną funkcję jednostkową i społeczną, a rozdzielanie ich tworzy sztuczną przewagę tych drugich. Sztuczną, gdyż większość wartości reprezentowanych przez wytwory wysokiej kultury odwołuje się do innej kategorii. W zależności więc od produktu kultury poszczególne pola wartości produktu kultury mogą mieć różny potencjał. W produktach popkulturowych większe znaczenie może mieć pole użyteczności - produkt taki może odnosić się do sfery osobistych uświadomionych korzyści. Mniejsze znaczenie może mieć natomiast pole estetyki, chociaż ono również istnieje. W produktach kultury wysokiej może być zgoła odwrotnie: możemy mieć do czynienia z rozbudowanym polem estetyki i niewielkim polem użyteczności ${ }^{31}$. Oba wspomniane produkty mogą natomiast dysponować zbliżonym potencjałem pola spekulacyjnego. Tymczasem można wyobrazić sobie produkt kultury popularnej z rozbudowanym polem estetyki i jednocześnie produkt zaliczany do kategorii elitarnej, który w zasadniczym stopniu zwraca się w kierunku wartości użytkowych. Przeanalizujmy ten wątek dogłębniej, przyglądając się poszczególnym polom wartości oraz ich wzajemnym oddziaływaniom.

\section{Pole użyteczności produktu kultury}

Jeśli produkt reprezentuje wartość użyteczną, oznacza to, że jest on w jakikolwiek sposób przydatny - gdzie przydatność to wewnętrzne znaczenie korzyści powstałe w świadomości człowieka, a nie immanentna cecha produktu. Produkt może być przydatny, gdy zaspokaja nasze uświadomione potrzeby biologiczne, emocjonalne i pragmatyczne. Odpowiednimi przykładami produktów kultury może być więc zarówno „popowa” piosenka czy występ kabaretowy, jak i podręcznik szkolny albo film dokumentalny, ale także utwór poetycki lub spektakl operowy.

Jak wskazuje John Stuart Mill, użyteczne jest to, co „przyjemne i piękne zarazem"32. Reprezentant ujęcia estetycznego w filozofii Benedetto Croce twierdził tymczasem, że ,sztuka rozważana w samej swej istocie nie ma nic wspólnego ani z pożytkiem, ani z przyjemnościq" "33. Mill nie podzielał takiego punktu widzenia; twierdził na przykład, że „Sztuka muzyczna jest dobra, a to z przyczyny, że w liczbie innych jej skutków, sprawia przyjemność"34. Znów mamy do czynienia z konfliktem, którego przedmiotem są różnice w spojrzeniu na wytwory kultury. Nie wydaje się on jednak zasadny. Przyjemność nie jest bowiem właściwością sztuki, jej istotą;

31 Wyodrębnienie i nadanie znaczenia polu użyteczności w odniesieniu do dzieł artystycznych może być „nie w smak” wielu badaczom; odrzucanie jednakże spraw „niesmacznych” nie powoduje, że przestają one istnieć.

32 J.S. Mill, O wolności. O zasadzie użyteczności, Warszawa 2003, s. 184.

${ }_{33}$ B. Croce, Zarys estetyki, Warszawa 1962, s. 30.

34 J.S. Mill, $O$ wolności..., s. 180. 
jest natomiast obrazem emocjonalnym dzieła sztuki w świadomości jego odbiorcy. W tym oto znaczeniu możemy stwierdzić, że sztuka jest „dobra”, gdyż sprawia nam przyjemność. Poza tym użyteczne nie musi być wyłącznie przyjemne, ale też, jak wskazał Mill, również piękne. Rzecz jasna, istnieją różne kategorie piękna, każdy człowiek ma własną. Jeśli jednak uświadamiamy sobie, że produkt kultury jest piękny, mamy na myśli jego konkretną wartość użyteczną. Jego piękno jest dla nas odczuwalną korzyścią: piękno to jest to, co nam się podoba, co nas wzrusza, albo to, co może nas pozytywnie nastrajać. Jeśli wizerunek kobiety z obrazów Rubensa jest dla nas piękny, wówczas dzieła malarza nabierają wymiaru użytecznego. To, że coś jawi się nam jako przyjemne lub piękne, nie oznacza, iż przestaje być sztuką.

Wydaje się jednak, że w przypadku produktów kultury, które odnoszą się do ludzkich przyjemności, pole użyteczności jest symbolicznie bardziej wyraziste niż w przypadku produktów związanych z pięknem (choć oczywiście istnieją produkty, które są zarazem przyjemne i piękne). W sposób bardziej bezpośredni i jednoznaczny oddziałuje bowiem na człowieka przyjemność niż piękno. I zapewne w naszym otoczeniu odnajdziemy więcej ,przyjemnych” produktów kultury niźli „,pięknych”.

Istnieje wiele popularnych utworów muzycznych, które kojarzone są na całym świecie i rozpoznawalne przez dwa lub trzy pokolenia słuchaczy. Wake Me up Before You Go-Go, zaśpiewany przez George’a Michaela z grupy Wham!, z całą pewnością jest jednym z takich przebojów. Pod koniec roku 2015 serwis internetowy Spotify udostępnił ciekawe zestawienie. Otóż piosenka Michaela znalazła się na szczycie tego rankingu w kategorii shower (,,prysznic”). Okazało się, że amatorzy kąpieli pod prysznicem codziennie odtwarzają 550 tysięcy utworów muzycznych, by umilić sobie czas spędzony w łazience. W tej grupie najczęściej słuchana jest właśnie piosenka George’a Michaela ${ }^{35}$. Mamy doskonały przykład produktu kultury ze szczególnie zaakcentowanym polem użyteczności. Korzyść w postaci uczucia przyjemności, jaką otrzymuje konsument, jest niewątpliwa i nie wymaga dodatkowego komentarza.

„Prysznic" to przykład playlisty. Obejmują one utwory muzyczne w danej kategorii i, jak informuje serwis Spotify, są „utworzone przez użytkowników i przez Spotify” oraz „związane z popularnymi czynnościami i nastrojami” ${ }^{36}$. Podkreślmy w tym miejscu istotną sprawę. Skoro tworzenie playlist odnosi się zarówno do nastrojów, jak i czynności, wobec tego motywacja słuchania utworów muzycznych nie może być oparta wyłącznie na przyjemności. Świadczą o tym nazwy playlist. Obok wspomnianej kategorii ,prysznic”, w serwisie Spotify odnajdziemy inne, na przykład takie: „trening”, ,impreza”, ,,podróż do pracy”, „turystyka”, „,do kolacji”37. Wynika stąd, że użyteczność produktów kultury wyraża się także w praktycznym zastosowaniu. Muzyka nie tylko może sprawiać przyjemność, lecz także towarzyszyć nam w odpowiednich sytuacjach i miejscach.

${ }^{35}$ N. McAlone, Spotify told us the top 20 songs people listen to in the shower-here they are, Businessinsider.com, 01.10.2015, http://www.businessinsider.com/best-shower-songs-according-to-spotify-2015-10 [odczyt: 10.06.2016].

${ }^{36}$ Spotify.com, https://www.spotify.com/pl/brands/targeting/ [odczyt: 10.06.2016].

37 Tamże. 
Praktyczna strona produktów kultury może się też wyrażać w inny sposób. Po pierwsze, chodzi o aspekt naukowo-poznawczy, czemu służą podręczniki, słowniki, encyklopedie, prasa, portale i blogi internetowe, filmy dokumentalne i naukowe, prezentacje, lekcje, wykłady, warsztaty i wiele innych. Albumy, atlasy czy przewodniki mogą mieć zastosowanie w innych sytuacjach, np. przy okazji planowania podróży. Dzieła sztuki z kolei, a konkretnie ich wartość, można traktować jako inwestycję. Wreszcie, kolekcjonerskie wydawnictwa książkowe czy przedmioty sztuki użytkowej, ale wysokiej przecież także, mogą wpływać na podniesienie walorów estetycznych pomieszczenia, w którym są udostępnione.

Pole użyteczności odwołuje się zatem do świadomych wrażeń konsumenta związanych z przyjemną, piękną i praktyczną stroną produktu kultury. Nie musimy jednakże dodawać, że doznania te nie są czymś stałym. Różne produkty mają różną użyteczność. Ten sam produkt w ocenie różnych konsumentów może być mniej lub bardziej użyteczny. Użyteczność danego produktu może też być zmienna w czasie. Każdy człowiek po dokonaniu własnej, wewnętrznej oceny produktu może stwierdzić, iż aktualne spożytkowanie go nie przyniesie mu tylu korzyści, ile otrzymywał wcześniej, więc w rezultacie może postrzegać go jako nieużyteczny, choć przecież sam z siebie taki nie jest - nie zmienił się. Są oczywiście osoby, w pewnym sensie wyjątkowe, które świadomie kierują się w stronę „,brzydkości” czy „niepraktyczności” produktów, jednak jeżeli odczucia takie są przez nie pożądane, to w ostatecznym rozrachunku będą traktowane jako przyjemne, a produkt będzie postrzegany jako użyteczny. Niektórzy wszakże nawet z cierpienia czerpią przyjemność.

\section{Pole spekulacji produktu kultury}

Za sprawą wchodzenia we wzajemne interakcje, komunikowania się, ludzie uzgadniają to, jak wygląda otaczająca nas rzeczywistość i jakie ma dla nas znaczenie. Mówi o tym teoria konstruktywizmu społecznego, na której rozwój w zasadniczy sposób wpłynęła praca Petera Bergera i Roberta Luckmanna z 1966 roku The Social Construction of Reality ${ }^{38}$. Rzeczywistość tworzymy na bieżąco, negocjując coś w rozmowie (np. podczas zebrania zarządu), albo pozyskujemy gotowe, wcześniej uzgodnione konstrukcje świata (np. w ramach lekcji szkolnych, poprzez media). Te społeczno-kulturowe konstrukcje traktujemy jako wiarygodne oraz ważne - i takimi je zapamiętujemy. Służą nam one do właściwego rozumienia tego, co nas otacza. Oczywiście, ich charakter jest płynny, są stale renegocjowane i ponownie uświadamiane. Są tworami subiektywnymi - są obecne wyłącznie w ludzkiej świadomości.

Pole spekulacji jest takim właśnie konstruktem kulturowym odnoszącym się do konkretnego produktu. Stanowi świadome znaczenie tego, że produkt jest ważny nie z własnego punktu widzenia, ale ze społecznego. Można powiedzieć, że to pewien rodzaj społecznej rekomendacji, że produkt jest wartościowy.

${ }^{38}$ Polskie wydanie książki: P.L. Berger, T. Luckmann, Społeczne tworzenie rzeczywistości, Warszawa 1983. 
Określenie ,pole spekulacji” może wywoływać pejoratywne odczucia. Nie będą nas jednak interesować oparte na dużym ryzyku, często wątpliwe czynności manipulowania instrumentami finansowymi. Chodzi natomiast o podkreślenie spekulacyjnego charakteru nadawania znaczeń produktom kultury, które to znaczenia są wielokrotnie renegocjowane i przestają mieć związek z rzeczywistością. Dyskusje społeczne przestają bowiem dotyczyć samego produktu, oscylują natomiast wokół społecznie skonstruowanej jego wartości. Mamy tutaj zatem do czynienia ze zjawiskiem tworzenia znaczeń w odniesieniu do znaczeń wcześniej zbudowanych. W świecie artystyczno-medialnym jest wiele przykładów tego typu. W dużej mierze dotyczy to osób nazywanych potocznie celebrytami, o których mówi się często, iż: ,znane są z tego, że są znane". To pozornie banalne określenie wiele wnosi do naszej dyskusji. Warto bowiem zwrócić uwagę, że przestajemy mówić o przymiotach tych osób, deliberujemy natomiast o tym, dlaczego i w jaki sposób są ważne (gdyż pokazują się w takim a takim towarzystwie, uczestniczą w takich a takich imprezach, tu a tu jadą na wakacje, takich a takich używają kosmetyków etc.). Osoby te stają się coraz bardziej znane i zarazem coraz ,ważniejsze”. W tym kontekście uwaga Philipa Kotlera, że osobę można traktować jak produkt (kultury), wydaje się wyjątkowo trafna.

To, że coś postrzegamy jako ważne dzięki temu, iż to coś jest znane, nie odnosi się tylko i wyłącznie do produktów kultury popularnej. Pomimo że Jeff Koons jest przedstawicielem sztuki współczesnej, a jego prace licytowane są przez najbardziej uznane domy aukcyjne, jego popularność jest porównywalna do ikon popkultury. W 2013 roku dom aukcyjny Christie's zlicytował rzeźbę artysty Baloon Dog (orange) za kwotę 58,405 mln dolarów ${ }^{39}$. Nikt wcześniej nie zapłacił więcej za zlicytowane dzieło sztuki żyjącego artysty. Nie wydaje się jednak, że wynikało to z samej estetyki dzieła - w zasadzie to przecież dużej wielkości pomarańczowy, wykonany ze stali nierdzewnej przez pracowników artysty, balonowy pies, a artysta inspirował się dmuchanymi zabawkami, jakie tworzy się dla dzieci techniką skręcania balonu. Główną rolę odgrywa natomiast marka Jeffa Koonsa, czyli to, że jest znany. Koons sam dba o to, by o nim mówiono, stając się artystą celebrytą. W roku 1991 roku pobrali się z Iloną Staller, gwiazdą porno, bliżej znaną pod pseudonimem Cicciolina ${ }^{40}$. Choć związek przetrwał rok, artysta uzyskał dzięki niemu odpowiednią pozycję medialną. Z kolei Lady Gaga zawdzięcza Koonsowi projekt okładki albumu Artpoop, on natomiast - lokowanie produktu (czyli siebie) w tekście jej piosenki Applause: „W jednej chwili jestem Koonsem, potem nagle Koons jest mną"41. Swoją pozycję rynkową kreował, wiążąc się także ze znanymi markami: odzieżowymi - z H\&M ${ }^{42}$ oraz projektantkami Stellą McCartney i Lisą Perry, alkoholowymi - przygotował

${ }^{39}$ Christies.com, http://www.christies.com/lotfinder/sculptures-statues-figures/jeff-koons-balloon-dog-5739099-details.aspx [odczyt: 14.06.2016].

${ }^{40}$ D. Rosenbaum, Jeff Koons zrobi wszystko za pieniądze, Vumag.pl, 27.11.2013, http://vumag. pl/ludzie-styl-zycia/jeff-koons-zrobi-wszystko-za-pieniadze/bfzjl [odczyt: 14.06.2016].

${ }^{41}$ M. Stalmerska, Jeff Koons - najdroższy żyjacy artysta. Balonowy król, Czasnawnetrze.pl, 14.06.2016, http://czasnawnetrze.pl/malarstwo-polskie/sylwetki-artystow/17551-jeff-koons-najdrozszy-zyjacy-artysta-balonowy-krol [odczyt: 14.06.2016].

42 Tamże. 
projekt opakowania na butelkę szampana Don Pérignon, jak też motoryzacyjnymi koncepcja karoserii modelu bmw. Artysta powołał także organizację pożytku publicznego The Koons Family Institute on International Law \& Policy ${ }^{43}$.

Jednak nie tylko na rozpoznawalność należy zwrócić uwagę. Żeby jakikolwiek produkt kultury odbierać jako ważny, powinien także cieszyć się uznaniem, a jako uznanie należy rozumieć podkreślenie wartości produktu przez autorytet. $Z$ jednej strony autorytetem mogą być dla nas konkretne osoby lub grupy osób nam bliskie, z drugiej - organizacje o ugruntowanej marce w świecie twórczo-artystycznym. W pierwszym przypadku mamy do czynienia z rodzajem marketingu szeptanego, kiedy to zaufana osoba rekomenduje nam dany produkt. Druga sprawa wymaga szerszego omówienia.

Jednym z najbardziej skutecznych środków podnoszącym wartość produktu kultury są nagrody. Nagradzanie dzieł sztuki przestało być jednak czymś wyjątkowym - każdy współczesny „dobry” utwór powinien być uhonorowany czy wyróżniony. Nie dziwi więc to, ,że przed końcem XX wieku liczba nagród filmowych wręczanych każdego roku przekroczyła liczbę produkowanych w tym samym czasie filmów pełnometrażowych"44. Podobna sytuacja jest zresztą w środowiskach literackich ${ }^{45}$. Przy okazji warto podkreślić wzrost znaczenia samych uroczystości wręczania nagród. Wiele osób oczekuje oskarowego wieczoru jak igrzysk olimpijskich, gdzie górę biorą emocje wynikające z samej rywalizacji niż z twórczego (tudzież sportowego) potencjału. Jednakże pomimo dewaluacji wartości nagród, najbardziej cenione są te o silnej marce, choćby: Złota Palma (film), Pulitzer (literatura), Grammy (muzyka), World Press Foto (fotografia dziennikarska).

Warto zauważyć, że uznanie w istocie skutkuje połączeniem dwóch marek - np. nagrody i filmu - co wynika z przeniesienia wartości uznanej marki na drugą, jeszcze nieutrwaloną w świadomości odbiorców. Wzmacnianie wartości produktów kultury w wyniku połączenia marek może się odbywać, jak wskazaliśmy, zwłaszcza poprzez: przyznanie nagrody, ale też udostępnianie publiczności wytworów kultury w znanych ośrodkach (np. sprzedaż w galeriach i domach aukcyjnych, takich jak: Christie's, Sotheby's czy Hôtel Drouot), opinię liczących się krytyków i recenzentów, współudział rozpoznawalnych artystów w wytworzeniu i promocji produktu kultury (znany aktor, kompozytor itp.) czy rekomendację medialną (np. zamieszczenie logo kojarzonej stacji telewizyjnej lub portalu internetowego na okładce filmu).

Jest rzeczą całkiem prawdopodobną, że pole spekulacji w krótkim czasie może osiągnąć „spore rozmiary”. Nie jest to zjawisko wyłącznie nam współczesne. Holandia znana jest z hodowli tulipanów. W pierwszej połowie XVII wieku część plantacji kwiatów zaatakował wirus, za sprawą którego płatki kwiatów stały się w specyficzny sposób pomarszczone i postrzępione oraz zyskały oryginalne zabarwienie. Unikatowe zmiany dały początek ,gorączce tulipanowej”46. W krótkim czasie wartość kwia-

${ }^{43}$ D. Rosenbaum, Jeff Koons... [odczyt: 14.06.2016].

44 J.F. English, Ekonomia prestiżu, Warszawa 2013, s. 212.

45 Tamże, s. 213.

46 P.M. Garber, Famous First Boubbles, „The Journal of Economics Prespectives” 1990, vol. $4 / 2$, s. $35-54$. 
tów przestała być związana z ich wyjątkowością, natomiast wciąż się zwiększała za sprawą burzy komunikacyjnej na rynku. Z kolei niedługo potem o wartości produktu zaczęła decydować przede wszystkim jego cena (sama w sobie także będąca tworem społecznym). Stało się to w momencie, gdy ceny cebulek tulipana osiągnęły pułap inwestycyjny, w związku z czym poza hodowcami zainteresowanie nimi zaczęli wyrażać również inwestorzy. Zjawisko wymknęło się spod kontroli - cena samoistnie zaczęła się zwielokrotniać. Procesu tego nie udało się zahamować i ostatecznie w roku 1637 zabrakło chętnych do zakupu cebulek tulipana, doszło do pęknięcia bańki spekulacyjnej, a skutkiem tego było bankructwo wielu osób.

Cena produktu ma zasadnicze znaczenie - może go stworzyć towarem luksusowym, a to podkreśla jego wagę społeczną. Dotyczy to zarówno produktów popkulturowych, jak i tych uznawanych za dzieła artystyczne. Popyt zarówno na jedne, jak i drugie coraz częściej wiąże się z wysoką ich ceną. A ponieważ w ostatnich latach ceny dóbr kultury wzrastają wykładniczo, w podobny sposób zwiększa się także zainteresowanie nimi. Między rokiem 2004 a 2014 wartość rynku sztuki zwiększyła się o ponad $150 \%$. Kwoty sprzedanych dzieł sztuki zwielokrotniają się i biją kolejne rekordy. Pomiędzy 1999 a 2007 rokiem wartość obrazu Andy Warhola wzrosła z 2 mln do 24 mln dolarów ${ }^{47}$. W roku 2015 dom aukcyjny Christie's sprzedał obraz Pabla Picassa Kobiety z Algieru za 179,4 mln dolarów, który tym samym stał się najdroższym dziełem sztuki sprzedanym na aukcji. Tymczasem w 1997 roku ten sam obraz sprzedano za $32 \mathrm{mln}^{48}$. Powyższe przykłady wyraźnie wskazują na to, iż zmniejsza się estetyczna wartość sztuki, zwiększa się natomiast jej ranga społeczna, a zarazem zmienia się jej subiektywne znaczenie i nastawienie wobec niej. Adorno mylił się więc, twierdząc, że tylko ludyczna twórczość artystyczna może podlegać utowarowieniu.

Luksusowy produkt kultury nie musi być jednak wyłącznie rezultatem ustanawiania cenowych rekordów. Na masowym rynku kultury znaczenie mają również wysokie wskaźniki sprzedanych produktów - można im wówczas przyznawać specjalne „luksusowe tytuły”, np. złotej czy platynowej płyty. Często także luksusowe produkty wytwarza się zupełnie od podstaw, choćby kolekcjonerskie tudzież limitowanej edycji.

Jest jeszcze jeden parametr, który wskazuje na to, że produkt kultury jest ważny. Powinien być mianowicie modny. Modę należy pojmować jako nawiązywanie do konkretnych nurtów społecznych. Elementy mody ukryte w produkcie kultury mogą nawiązywać zarówno do kultury popularnej, jak i odcinać się od niej, czerpiąc z innych wpływów, np.: elitarnych, niszowych, krytycznych. Każda natomiast moda może być bezrefleksyjnie powielana, jak też stanowić świadomą strategię. Wytwory artystyczne wspomnianego Jeffa Koonsa, ale także Andy Warhola są przykładem

47 Zob.: A. Georgina, Big Bucks: The Explosion of the Art Market in the 21st Century, London 2014.

${ }^{48}$ Rynekisztuka.pl, „Kobiety z Algieru” Picasso najdroższym dziełem świata!, 13.05.2015, http://rynekisztuka.pl/2015/05/13/kobiety-algieru-picasso-najdrozszym-dzielem-swiata/ [odczyt: 14.06.2016]. 
tego, że moda popularna może być tematem przewodnim w sztuce i zwiększać jej wartość. I odwrotnie, „oddolne” trendy mogą być wykorzystywane przez twórców reprezentujących ,popularne” rynki artystyczne. Przykładem jest Tajemnica Brokeback Mountain z 2005 roku, film, w którym po raz pierwszy w niezakamuflowany sposób ukazano miłość dwóch mężczyzn. Nie można wykluczyć tego, że tematyka filmu przełożyła się na jego sukces komercyjny.

Popularność, uznanie, luksus i moda wyrażone w produkcie kultury mają zatem wpływ na uświadomioną jego wartość społeczną, czyli ważność. Oczywiście, różne produkty kultury będą reprezentowały różną ważność społeczną, toteż nie każdy z nich trafi do tego samego odbiorcy. Pole spekulacji produktu kultury nie zawsze koresponduje ze społecznym ,ja” człowieka. Jednak czasami może być ono rozbudowane do takiego stopnia, że człowiek nie oprze się jego oddziaływaniu i zmieni swoje wewnętrzne nastawienie. Wówczas wcześniejsze preferencje stają się nieaktualne, gdyż nowe postrzega się jako ważniejsze.

\section{Pole estetyki produktu kultury}

Utwory artystyczne są wyrażeniem marzeń człowieka. Zwraca na to uwagę Zygmunt Freud, który twierdzi, że marzenia są „surowcem tworów poetyckich; albowiem poeta ze swoich marzeń na jawie, przekształcając je, opracowując i skreślając, tworzy sytuacje, które umieszcza później w swoich nowelach, powieściach i sztukach teatralnych"49. Rzecz jasna, dotyczy to zarówno dzieł literackich, jak i każdych innych form wyrazu; zarówno sztuki wysokiej, jak i popularnej. Twórczość nie jest jednak odwzorowaniem tych marzeń; one są nieuchwytne. Marzy się w inny sposób niż się tworzy, dlatego też każde dzieło sztuki będzie tylko pewnym fizykalnym przybliżeniem marzeń, wyrażonym w odpowiednim języku. To niedokładne odwzorowanie sprawia, że język przedstawia, ale też zasłania to, co jest istotą tworzenia. O barierze tej wspominał Ludwig Wittgenstein: „Język przysłania myśl. Tak mianowicie, że po zewnętrznej formie szaty nie można sądzić o formie przybranej w nią myśli” ${ }^{50}$. Wydaje się, iż „tłumaczenie” przez artystę jego marzeń (myśli) na język nie jest uświadomione, odbywa się natomiast spontanicznie, niejako pod wpływem „chwili”. Zgodzić się należy więc z Benedettem Crocem, według którego sztuka jest „intuicją" ${ }^{51}$. Intuicja nie jest bowiem myśleniem rozumowym, jest dokonywaniem wyborów bez udziału woli.

Freud podkreśla jednak to, że język (rozumiany jako twórczy środek wyrazu) „nie jest czymś przypadkowym, lecz osadem dawnej wiedzy”52. Wszystko, co człowiek tworzy, jest wykonane przy użyciu określonego języka. Żeby odkryć znaczenie przekazu językowego, należy dokonać jego interpretacji. Każdy człowiek ma

\footnotetext{
49 Z. Freud, Wstep do psychoanalizy, Kęty 2010, s. 66.

${ }^{50}$ L. Wittgenstein, Tractatus logico-philosophicus, Warszawa 1997, 4.002.

${ }^{51}$ B. Croce, Zarys..., s. 27.

${ }^{52}$ Z. Freud, Wstęp do..., s. 65.
} 
taką wewnętrzną predyspozycję, gdyż - jak zauważa Carl Gustav Jung - dysponuje on pewnymi historycznie ugruntowanymi, pierwotnymi formami, wzorcami czy wizerunkami znaczeniowymi, które stanowią niejako początkowy punkt odniesienia do otaczającej nas rzeczywistości ${ }^{53}$. Dzięki nim właściwie odczytujemy znaczenie otaczającego nas języka. Tym historycznym pierwowzorom Jung przypisał pojęcie archetypów. To właśnie archetypy są osadem wskazanej przez Freuda „dawnej wiedzy” i choć są treścią nieświadomości człowieka, gdzie nie przyjmują żadnej określonej postaci, to mogą się uzewnętrzniać w postaci określonego języka (np. w twórczości artystycznej). W ten oto sposób ukryta „dawna wiedza” przenika w postaci języka do naszej „,codzienności”.

Archetypy mogą dotyczyć postaci, idei, zdarzeń, przedmiotów, postaw, motywów, uczuć, zachowań i wielu innych. Ponieważ są wartością uniwersalną, każdy człowiek dzięki nim jest w stanie zrozumieć na przykład to: kim jest żebrak, co to jest podróż lub czym jest stół. W naszym otoczeniu archetypy skrywają się więc m.in.: w ludzkich zachowaniach, teoriach, produktach, utworach, nazwach. Warto przy okazji zauważyć, iż starożytni Sumerowie wyrażali przekonanie, że we wszystkich istniejących bytach, ,zarówno w materialnych, jak też pojęciach abstrakcyjnych określających poszczególne dziedziny życia oraz stany indywidualne i duchowe" istnieje me - czyli ,indywidualna siła [która] utrzymuje każdą jednostkę kosmiczną we właściwym dla niej bycie" ${ }^{54}$. Możemy zatem podkreślić, że zagłębiając się w język każdego bytu (w tym produktów kultury), mamy szansę ukazać ich archetypiczny fundament.

Pole estetyczne produktu kultury wiąże się więc z ukrytymi w nim archetypicznymi wzorami, pochodzącymi z nieświadomości twórcy i spajającymi się z nieświadomością odbiorcy produktu. Śladów archetypów zawartych w dziele sztuki nie potrafimy precyzyjnie nazwać, możemy je tylko odczuwać. Zarówno artysta nie myśli o nich, gdy tworzy, tak samo i odbiorca dzieła tego nie robi. Pole estetyki traktuje więc o tych sferach produktu kultury, które powodują, że u tego drugiego pojawia się uczucie oczarowania. Nie wie on jednak, czym konkretnie jest oczarowany; bynajmniej nie pięknem dzieła, w tym znaczeniu, że ono mu się podoba, gdyż ,podobanie się" - na co zwraca uwagę Roman Ingarden - ,jest stanem lub przeżyciem świadomym”55. Człowiek świadomy dokonuje ocen i wyborów, tymczasem ,„[w]artość estetyczna nie jest jednak - jak to się nieraz słyszy - wy tw orem oceny i nie ta ocena jest jej podstawą bytową" ${ }^{56}$.

By produkt kultury mógł w jakikolwiek sposób oczarować swojego odbiorcę, nie może być wytworzony językiem standardowym, to znaczy takim, który odczytujemy w sposób w miarę jednoznaczny. Jeżeli powiemy, że produkt kultury jest piękny, a podoba nam się w nim to a to, że sprawia on nam przyjemność, a konkretnie to

53 C.G. Jung, The Archetypes and the Collective Unconscious [w:] H. Read (red.), The collected works of C.G. Jung, London 1968.

${ }^{54}$ K. Łyczkowska, K. Szarzyńska, Mitologia Mezopotamii, Warszawa 1981, s. 56.

${ }_{55}$ R. Ingarden, Studia z estetyki, t. II, Warszawa 1958, s. 106.

56 Tamże, s. 105. 
i to, mamy wówczas do czynienia z użyteczną, a nie estetyczną stroną produktu. Zidentyfikowane i nazwane archetypy przestają nimi być. Język produktu kultury musi być zatem oryginalny w taki sposób, aby zawarte w nim nieświadome wzorce archetypiczne (ideały, smutki, radości, potrzeby, pożądania i inne) pozostały nieczytelne, bezpostaciowe i nie stawały się uświadomionymi wartościami w przestrzeni użytecznej (,,ja-ja”) lub spekulacyjnej (,,ja-oni”). Archetypy nie mają wymiaru ani indywidualnego, ani społecznego - są i takie, i takie oraz ani takie, ani takie. Nie ma też gorszych i lepszych archetypów. Jeżeli więc artysta sięga po oryginalne środki wyrazu, by w sposób inny od wcześniejszych twórców przedstawić swoje marzenia, pole estetyki będzie w większym stopniu oddziaływać na odbiorcę niż w przypadku dzieła powstałego na podstawie znanych rozwiązań twórczych. Oryginalne będzie zatem podążać ku estetycznemu, standardowe - ku użytecznemu. Artysta używający standardowych form wyrazu przestaje być twórcą.

Wspomnieliśmy, że archetypów nie można odczytać, a te, które są nazwane, przestają być archetypami. Doświadczając produktu kultury, możemy natomiast wyczuwać „obecność” archetypów. Wpływają i kształtują one bowiem nasz nieświadomy stan estetyczny. To właśnie dzięki temu odczuciu możemy je opisać, jednakże tylko w pewnym przybliżeniu, nigdy nie docierając do ich natury. Oczarować nas mogą zarówno produkty kultury popularnej, jak i wysokiej, oryginalny język nie jest bowiem przypisany wyłącznie konkretnym bytom. A skoro tak, to wszystkie produkty kultury, których wspólnym motywem jest pierwiastek twórczy, korespondować będą w większym lub mniejszym stopniu z nieświadomością człowieka, w związku z tym będą posiadać własne pole estetyki.

Dotyczy to także sztuki nawiązującej do kultury masowej, autorstwa wspomnianego wcześniej Jeffa Koonsa. Pole estetyki rzeźby Baloon Dog (orange) jest oczywiście oparte na innym fundamencie archetypicznym niż klasyczne dzieła sztuki, nie oznacza to jednak, że ono nie istnieje, że język artystyczny obiektu nie jest oryginalny, a osoba doświadczająca go nie czuje się oczarowana. Spróbujmy zastanowić się zatem, do jakich „osadów” archetypicznych odwołuje się rzeźba, tworząc nieco syntetyczną listę ich określeń; syntetyczną, gdyż, jak wspomnieliśmy, archetypów nie da się określić. Baloon Dog (orange) jest właściwie dziełem sztuki-zabawką, dlatego też pojawiają się tutaj przede wszystkim wzory archetypiczne związane z dzieciństwem ${ }^{57}$, takie jak: zabawa czy też bajka, uśmiech, radość, szczęście, wspomnienia. Jednocześnie pojawia się archetypiczny pies i powiązane z nim inne motywy: zwierzę, przyjaciel, opieka, czułość, przygoda. Kolejne grupy archetypów odnoszą się do fizykalnej natury dzieła, które pozostają z sobą w sprzeczności. Z jednej strony są to: delikatność, lekkość, nietrwałość, które odwołują się do „balonowej” natury obiektu, z drugiej: wielkość, kolos, olbrzym, monstrum (rzeczywiste wymiary wynoszą: 307,3 x 363,2 x 114,3 cm ${ }^{58}$ ). Takie starcie skrajnie różnych motywów kulturowych

57 Przykład zastosowania „dziecięcego” archetypu do opisu i zrozumienia fenomenu organizacji podaje Monika Kostera: zob. M. Kostera, Archetypy i organizacje, Warszawa 2010, s. 185-199.

${ }^{58}$ Christies.com, http://www.christies.com/lotfinder/sculptures-statues-figures/jeff-koonsballoon-dog-5739099-details.aspx [odczyt: 22.06.2016]. 
może skutkować pojawieniem się u człowieka doznań archetypicznych opartych na nieprawdzie, takich jak: fałsz, kamuflaż, imitacja.

Dzięki tej krótkiej archetypicznej analizie dzieła Koonsa możemy przyjrzeć się, na jakich wzorcach kulturowych koncentruje się jego oryginalność. Otóż wydaje się, że to, co świadczy o niepowtarzalności czy unikatowości rzeźby, odnosi się do ukrytych w jej języku archetypów dzieciństwa - mamy tutaj do czynienia z infantylizacją sztuki - oraz archetypów nieprawdy. Najprawdopodobniej to one w zasadniczym stopniu „oczarowują” odbiorcę dzieła.

Powyższe fundamenty archetypiczne są wykorzystywane przez Jeffa Koonsa w wielu innych jego pracach. Kategoria nieprawdy oraz infantylizacja pojawiły się na przykład w jednym z projektów sztuki użytkowej - w opakowaniu na butelkę, przygotowanym dla znanej marki alkoholowej Don Pérignon. Artysta inspirował się przy tym odnalezioną na terenie Austrii kamienną figurką paleolityczną nazwaną Wenus z Willendorfu, przedstawiającą nagą postać kobiety z charakterystycznie uwydatnionymi „kobiecymi” cechami. Opakowanie przybrało więc postać fioletowej „balonowej Wenus”. Mamy tutaj widoczne zarówno archetypiczne motywy infantylizmu, nieprawdy, jak i inne, nawiązujące do klasycznych archetypów płodności, matki, narodzin czy życia, ukazane natomiast w oryginalny sposób w niepoważnej postaci: żartu, farsy, kpiny.

Każdy produkt kultury będzie posiadał więc własne pole estetyczne. Może ono być bardziej lub mniej rozbudowane i bardziej lub mniej oddziałujące na odbiorcę w zależności od tego, jak bardzo jest ono oryginalne. Oryginalność produktu wpływa na oczarowanie nim odbiorcy. Można je osiągnąć, kierując się w stronę niestandardowych rozwiązań w projekcie produktu, będących wyrazem nieświadomych archetypicznych marzeń twórcy.

\section{Relacje pomiędzy polami wartości produktu kultury}

Roland Barthes w oryginalny sposób podchodzi do kwestii przyjemności. Postrzega ją w dwóch wymiarach - jako: joussance (rozkosz) oraz plasir (przyjemność) ${ }^{59}$. Pierwsza związana jest z cielesnością człowieka i dotyczy jego somatyczno-ekstatycznych uniesień, które mogą się ujawniać nawet podczas czytania książek czy słuchania piosenek - mówimy tutaj jednak o „,czytaniu ciałem” niźli jakimś głębszym procesie. Rozkosz jest wtórna i jest niejako odczłowieczeniem, co badacz podkreśla, zwracając uwagę, że ,ja” człowieka tworzone jest społecznie, a każde skierowanie się ku własnemu ciału jest wyrywaniem się z tej społecznej tożsamości i skutkuje jej zanikiem. Większą wartość ma zatem przyjemność społeczna (plasir). Wyraża się ona w społecznej aprobacie, szacunku, uznaniu, zgodności z obowiązującą ideologią. Człowiek pozostający z nią w zgodzie doznaje rzeczywistej przyjemności - pozostaje w społecznej harmonii.

59 Zob. R. Barthes, Przyjemność tekstu, Warszawa 1997. 
Spójrzmy na tę sprawę w nieco inny sposób. Wykazaliśmy wcześniej, że ,ja” człowieka budowane jest na dwóch płaszczyznach - w relacji do siebie i do innych. „Ja” jest wynikiem ciągłego ścierania się tych płaszczyzn; nie da się w związku z tym nadać którejkolwiek z nich większej rangi. Poza tym ,ja-ja" nie stanowi li tylko cielesnego uniesienia, ale wewnętrzne znaczenie tego, co jest dla mnie ważne bez pytania się o to innych. Podział przyjemności Barthes'a ma jednak znaczenie z naszego punktu widzenia. Przypomnijmy, że społeczno-kulturowy komponent produktu kultury nazwaliśmy polem spekulacji. Na il. 1 widać, że wchodzi ono w relację z polem użyteczności. Chodzi tutaj o to, że niektóre elementy produktu z pola spekulacji, mające wymiar społeczny, mogą „migrować” w kierunku pola użyteczności - wówczas będą traktowane jako ważne z indywidualnej perspektywy, a nie społecznego interesu. Do takich użytecznych, ale postspołecznych wartości można zaliczyć cenę, markę i modną treść produktu. Uczucie po dokonaniu zakupu biżuterii (która również jest produktem kultury) po odpowiednio wysokiej cenie może przecież objawiać się świadomością przyjemności. Wartość dzieła sztuki wyrażająca się w cenie (a nie w jego estetyce) może mieć także inne użyteczne znaczenie: inwestycyjne, czyli praktyczne. Mogą z kolei istnieć produkty kultury, które dzięki swej atrakcyjności społecznej, czyli temu, że są modne, stanowią dla nas wartość, jednak po jakimś czasie możemy przestać tak odczuwać, a to, co modne, może się przerodzić w indywidualną przyjemność. Warto także nadmienić, iż może także wystąpić sytuacja odwrotna, kiedy to pole użyteczne straci na znaczeniu wobec pola spekulacji. $\mathrm{Z}$ biegiem czasu zmieniają się przecież nasze preferencje osobiste, $\mathrm{w}$ tym czasie natomiast może powiększyć się na przykład społeczna wartość kolekcjonerska produktu kultury.

Inna jest relacja pola estetyki i spekulacji oraz estetyki i użyteczności. Przypomnijmy, że pola wartości są niematerialną tkanką produktu kultury jawiącą się w świadomości i nieświadomości konsumenta. Pole estetyki odwołuje się do nieświadomości człowieka, natomiast pola spekulacji i użyteczności - do warstwy uświadomionej. W nieświadomości ,ja" nie istnieje, ukryte są natomiast bezpostaciowe archetypy, które, w sytuacji ich uświadomienia, stają się tworzywem ludzkiego ,ja”. Przykładowo, archetypiczna miłość jest bezpostaciowa, tymczasem uświadomiona z jednej strony staje się osobistym uczuciem miłości, z drugiej - subiektywnym spojrzeniem na społeczne znaczenie miłości.

Wyrwane z obszaru marzeń i uświadomione archetypy przestają więc mieć znaczenie estetyczne. Te, które migrują do pola użyteczności, przestają oczarowywać, stają się natomiast konkretne, czyli przydatne. Twórca produktu kultury, który przy jego tworzeniu powiela schematy językowe zawarte w innych, wcześniejszych produktach, nie ma na celu zaskoczenia odbiorcy, daje mu jednakże dokładnie to, czego on oczekuje. To dosyć częste zjawisko, występujące na przykład przy produkcji rozrywkowych programów telewizyjnych. Pierwszy, oryginalny, który zaskakuje publiczność, staje się szablonem do tworzenia kolejnych, wskutek czego ich formuła przyjmuje standardową postać i nie powoduje oczarowania widza, może natomiast wywoływać spodziewaną użyteczną przyjemność. Archetypy mogą też migrować z pola estetyki do pola spekulacji. Oryginalność tematyki utworu artystycznego 
nie jest przecież do niego trwale przypisana, to rodzaj odczucia estetycznego. Jeżeli po pewnym czasie od chwili wytworzenia produktu kultury jego treść zaczyna się pokrywać z tym, co jest modne, popularne, czyli ważne społecznie, nie można więcej mówić o jego oryginalności. W taki oto sposób elementy pola estetyki mogą przechodzić do pola spekulacji. Produkt kultury przestaje nas oczarowywać, ale staje się dla nas ważny, ponieważ rekomendowany jest społecznie.

Bywa tak, że z rozmaitych powodów (bólu, jaki sprawiają, nieprzydatności) o różnych uświadomionych elementach naszego życia przestajemy pamiętać i wypieramy je $\mathrm{w}$ stronę nieświadomości ${ }^{60}$. Migracja pomiędzy omawianymi polami może w związku z tym przebiegać odwrotnie. Może być przecież tak, że produkt kultury przestaje być użyteczny: muzyka, która umilała nam drogę z domu do pracy, w pewnym momencie traci tę właściwość, zostaje zapomniana, wyparta do nieświadomości i zastąpiona inną, która spełnia nasze oczekiwania. Jednak po jakimś czasie może zdarzyć się sytuacja, że ,porzucona” muzyka ponownie ,wpadnie nam w ręce” i znowu usłyszymy w niej coś estetycznego, twórczego, oryginalnego, coś, o czym zapomnieliśmy z powodu rutynowej jej konsumpcji.

$\mathrm{Z}$ taką odwrotną migracją mamy również do czynienia na styku pola spekulacji i pola estetyki. Z pierwszego do drugiego mogą przepływać uświadomione konstrukcje społeczne i tam ulec zapomnieniu. Zwróćmy uwagę, że to, co kiedyś uchodziło za modne, znane, uznane czy nawet luksusowe (np. nawiązania do religii, moralności, patriotyzmu w sztuce klasycznej), obecnie wcale nie musi mieć takiej wagi społecznej. Tymczasem takie niepopularne, niepotrzebne elementy nie znikają, a wpadają do przestrzeni nieświadomości i pozostają tam niejako w „uśpieniu”. Produkty kultury, które przestały być ważne społecznie (lub użyteczne), w każdej chwili przecież ponownie mogą takimi się stać.

\section{Inspiracje aplikacyjne koncepcji pól wartości}

Powyżej omówiliśmy ideę pól wartości produktu kultury. Wykazaliśmy, że w każdym produkcie kultury można wyodrębnić niematerialną warstwę, złożoną z trzech wzajemnie powiązanych pól. Warstwa ta jest subiektywnym spojrzeniem, wewnętrznym obrazem korzyści, jaki tworzy człowiek przy okazji kontaktu z produktem.

Koncepcja pól wartości ma przede wszystkim znaczenie metodologiczne, istotne z punktu widzenia badaczy oraz przedsiębiorców działających na rynku kultury i innych rynkach, gdzie do wytworzenia produktu wymagany jest pierwiastek ludzkiej kreatywności. Badacze mogą wykorzystać to narzędzie w dwojaki sposób. Po pierwsze, mogą sami tworzyć obrazy pól wartości w odniesieniu do interesujących ich produktów kultury różnych kategorii, natomiast później dokonywać ich wzajemnego porównania. Można w ten sposób opowiedzieć na pytanie, do jakich klientów (reprezentujących jakie wartości) trafiają dane kategorie produktów, a ponadto, jakie

${ }^{60}$ Z. Freud, Wstęp do..., s. 49. 
rodzaje strategii symbolicznego oddziaływania na klientów stosują producenci. Po drugie, obrazów wartości nie musi tworzyć sam badacz, a może je pozyskać od potencjalnych konsumentów: od wyodrębnionej grupy badawczej, która podzieli się $\mathrm{z}$ badaczem swoimi wewnętrznymi refleksjami na temat doświadczanych produktów. Refleksje te powinny wchodzić w zakres każdego z trzech pól wartości: użyteczności, spekulacji i estetyki. O uświadomionych symbolicznych znaczeniach (pole użyteczności i spekulacji), osoba biorąca udział w eksperymencie może opowiedzieć badaczowi podczas wywiadu pogłębionego. Wywiady powinny oscylować wokół zagadnień przydatności (przyjemności, piękna i praktyczności) oraz ważności produktu (tego, czy jest znany, uznany, luksusowy i modny). Tymczasem nieuświadomioną wiedzę (z obrębu pola estetyki) możemy pozyskać za pomocą konotacji archetypicznych, a konkretnie, prosząc badanego, by wypisał na kartce zestaw na przykład dziesięciu jednowyrazowych skojarzeń odnoszących się do danego produktu. Wspomnieliśmy też, że subiektywny obraz wartości produktu jest dynamiczny, oznacza to, że wewnętrzne nastawienie odbiorcy wobec danego produktu zmienia się w czasie. Żeby zbadać zmiany w postrzeganiu produktu, powyższy eksperyment można przeprowadzić metodą panelową: wówczas kilkukrotnie, w stałych odstępach czasu, przeprowadzamy go wśród tej samej grupy odbiorców.

Podobne badania mogą prowadzić producenci. Po pierwsze, by poznać preferencje i zmiany preferencji własnych klientów. W ten sposób można zidentyfikować ich stosunek do nowych produktów czy też takich, które na przykład osiągnęły fazę dojrzałości. Po drugie, można też badać produkty konkurencji w tym celu, aby szukać inspiracji lub przeciwnie, aby unikać pewnych rozwiązań i nie popaść w standaryzację. Producenci mogą także analizować reklamy konkurencji (które same w sobie są przecież produktami kultury), by zidentyfikować rodzaj zastosowanych środków symbolicznych i stwierdzić, do jakiej grupy odbiorców są skierowane.

Warto też zwrócić uwagę, że w porównaniu z ilościowymi, przeprowadzenie badań jakościowych nie wymaga zaangażowania tak znacznych środków finansowych. Ważne są jednak odpowiednie umiejętności, by skrupulatnie pozyskać materiał badawczy, oraz pewien zasób potencjału twórczego, żeby interpretacja materiału nie miała powierzchownego charakteru. Toteż badania jakościowe mogą być z powodzeniem prowadzone także przez niewielkie organizacje.

Żaden produkt nie jest li tylko i wyłącznie tym, co „trzymamy w ręce”. Każdorazowo, gdy doświadczamy go, w naszej wyobraźni tworzy się świadomy i nieświadomy obraz jego wartości. To wówczas decydujemy, czy jesteśmy, czy też nie jesteśmy nim zainteresowani. By zatem rzetelnie przyjrzeć się temu, co powoduje, że produkt znajduje uznanie wśród nabywców, musimy uwolnić się od jego fizykalnej postaci, a dotrzeć do ludzkiej wrażliwości i wyobraźni, do jego wewnętrznego, ukrytego obrazu wartości. W wyniku przeprowadzonej analizy stwierdziliśmy, że ukryty obraz produktów kultury składa się z trzech pól: użyteczności, spekulacji oraz estetyki. W różnych produktach kultury w różnym stopniu położony jest akcent na poszczególne pola, niemniej każdy produkt kultury powinien oczarować odbiorcę (pole estetyki) oraz być dla niego ważny (pole spekulacji) i przydatny (pole użyteczności). 


\section{BIBLIOGRAFIA}

Adorno T., The Culture Industry, London 1991.

Barthes R., Przyjemność tekstu, Warszawa 1997.

Berger P.L., Luckmann T., Społeczne tworzenie rzeczywistości, Warszawa 1983.

Bourdieu P., Rozum praktyczny. O teorii działania, Kraków 2009.

Christies.com,http://www.christies.com/lotfinder/sculptures-statues-figures/jeff-koons-balloon-dog5739099-details.aspx. [odczyt: 22.06.2016].

Croce B., Zarys estetyki, Warszawa 1962.

Czarniawska B., Zarzadzanie humanistyczne czy zarzadzanie ludzkie? [w:] B. Nierenberg, R. Batko, Ł. Sułkowski (red.), Zarządzanie humanistyczne, Kraków 2015, s. 15-22.

Eco U., Dzieło otwarte: forma i nieokreśloność w poetykach współczesnych, Warszawa 1973.

English J.F., Ekonomia prestizu, Warszawa 2013.

Fiske J., Zrozumieć kulturę popularną, Kraków 2010.

Freud Z., Wstęp do psychoanalizy, Kęty 2010.

Garber P.M., Famous First Boubbles,„,The Journal of Economics Prespectives” 1990, vol. 4/2, s. 35-54.

Georgina A., Big Bucks: The Explosion of the Art Market in the 21st Century, London 2014.

Hatch M.J., Kostera M., Koźmiński A., Trzy oblicza przywództwa. Menedżer, artysta, kapłan, Warszawa 2010.

Heidegger M., Budować, mieszkać, myśleć. Eseje wybrane, Warszawa 1977.

Ilczuk D., Ekonomika kultury, Warszawa 2012.

Ingarden R., Studia z estetyki, t. II, Warszawa 1958.

Jung C.G., The Archetypes and the Collective Unconscious [w:] H. Read (red.), The collected works of C.G. Jung, t. 9, London 1968.

Kostera M., Antropologia organizacji. Metodologia badań terenowych, Warszawa 2003.

Kostera M., Archetypy i organizacje, Warszawa 2010.

Kostera M., Zarządzanie na rynku doznań [w:] B. Glinka, M. Kostera (red.), Nowe kierunki w organizacji i zarządzaniu. Organizacje, konteksty, procesy zarzadzania, Warszawa 2012, s. 361-375.

Kostera M., Collage narracyjny [w:] M. Kostera (red.), Metody badawcze w zarzadzaniu humanistycznym, Warszawa 2015, s. 81-91.

Kotler P., Marketing, Poznań 2005.

Krzyworzeka P., Kultura i organizacje. Perspektywa antropologiczna [w:] B. Glinka, M. Kostera (red.), Nowe kierunki w organizacji i zarzadzaniu. Organizacje, konteksty, procesy zarządzania, Warszawa 2012, s. 62-78.

Łyczkowska K., Szarzyńska K., Mitologia Mezopotamii, Warszawa 1981.

McAlone N., Spotify told us the top 20 songs people listen to in the shower - here they are, Businessinsider.com, 01.10.2015, http://www.businessinsider.com/best-shower-songs-according-to-spotify-2015-10 [odczyt: 14.06.2016].

Marks K., Kapitat, Warszawa 2012.

Mill J.S., O wolności. O zasadzie użyteczności, Warszawa 2003.

Orzechowski E., Arte et ratione [w:] B. Nierenberg, R. Batko, Ł. Sułkowski (red.), Zarzadzanie humanistyczne, Kraków 2015, s. 63-74.

Pine B.J, Gilmore, The Experience Economy: Work is the Theater and Every Business a Stage, Boston 1999.

Rosenbaum D., Jeff Koons zrobi wszystko za pieniądze, Vumag.pl, 27.11.2013, http://vumag.pl/ludzie-styl-zycia/jeff-koons-zrobi-wszystko-za-pieniadze/bfzjl [odczyt: 14.06.2016].

Rynekisztuka.pl, “Kobiety z Algieru” Picasso najdroższym dziełem świata!, 13.05.2015, http:// rynekisztuka.pl/2015/05/13/kobiety-algieru-picasso-najdrozszym-dzielem-swiata/ [odczyt: 14.06.2016]. 
Schmitt B., Simonson A., Estetyka w marketingu, Kraków 1999.

Sedlaček T., Ekonomia dobra i zła, Warszawa 2012.

Spotify.com, https://www.spotify.com/pl/brands/targeting/ [odczyt: 10.06.2016].

Stalmerska M., Jeff Koons - najdroższy żyjący artysta. Balonowy król, Czasnawnetrze.pl, 14.06.2016, http://czasnawnetrze.pl/malarstwo-polskie/sylwetki-artystow/17551-jeff-koons-najdrozszy-zyjacy-artysta-balonowy-krol [odczyt: 14.06.2016].

Strati A., Organization and Aesthetics, London 1999.

Strinati D., Wprowadzenie do kultury popularnej, Poznań 1998.

Throsby D., Ekonomia i kultura, Warszawa 2010.

Wittgenstein L., Tractatus logico-philosophicus, Warszawa 1997.

Zaltman G., Zaltman L., Metafora w marketingu, Poznań 2010. 